\title{
Synthesis of Ribosomal and Transfer Ribonucleic Acids in Yeast During a Nutritional Shift-up
}

\author{
By C. WALDRON* \\ Laboratoire de Génétique Physiologique, I.B.M.C., I5 rue Descartes, \\ 67000 Strasbourg, France
}

(Received 21 May 1976; revised 19 August 1976)

\begin{abstract}
SUMMAR Y
The growth rate of Saccharomyces cerevisiae was increased by adding a mixture of amino acids to cultures containing proline as the sole nitrogen source. The transition from balanced growth in the basal medium (doubling time $4 \mathrm{~h}$ ) to balanced growth in the enriched medium (doubling time $2 \mathrm{~h}$ ) took about $2.5 \mathrm{~h}$. The rate of RNA accumulation increased soon after the enrichment to almost its final value. This increase began after a short lag of Io to i $5 \mathrm{~min}$, therefore synthesis of new RNA polymerase molecules may be required before stable RNA production can increase. The different stable RNA species were not stimulated at different times after the enrichment, but all increased continuously throughout the transition. The rRNA species accumulated in a co-ordinate fashion at a rate faster than the rate of tRNA accumulation.
\end{abstract}

\section{INTRODUCTION}

The amount of stable RNA in yeast cells depends on their growth rate: fast-growing cells have a much higher RNA content than slow-growing cells (Wehr \& Parks, 1969; Boehlke \& Friesen, I975; Waldron \& Lacroute, 1975). The bulk of the stable RNA is rRNA and the remainder is tRNA but their relative abundance is also dependent on the growth rate: the ratio rRNA/tRNA is slightly higher in fast-growing cells than in slow-growing cells (Waldron \& Lacroute, 1975). These variations of RNA composition are very similar to those observed in bacteria (Rosset, Julien \& Monier, I966; Skjold, Juarez \& Hedgcoth, 1973) but they are likely to be achieved by different mechanisms because bacteria and yeast have different types of RNA polymerase. In bacteria there is one enzyme whose gene specificity is determined by whether or not it is associated with the polypeptide sigma (Burgess et al., 1969). In yeast there are three distinct nuclear RNA polymerases, each involved in the synthesis of a specific class of RNA (Adman, Schultz \& Hall, 1972; Ponta, Ponta \& Wintersberger, 1972).

Differences in the control of RNA synthesis may be expected to produce different responses to transitions in growth rate. When the growth medium of a bacterial culture is enriched there is an immediate increase in the rate of stable RNA production, preceding synthesis of new RNA polymerase molecules. Therefore, the stable RNA content of these cells must be controlled by the activity and not the amount of polymerase. The higher rate of stable RNA production is partly due to a faster RNA elongation rate, but largely results from an increase in the fraction of RNA polymerase molecules engaged in stable RNA synthesis (Nierlich, 1972; Bremer, Berry \& Dennis, 1973). Such a mechanism for increasing stable RNA production in yeast cells seems unlikely because the yeast polymerases which

* Present address: Botany School, South Parks Road, Oxford OXI 3RA. 
produce stable and unstable RNA have different sub-unit structures (Valenzuela et al., 1976).

The experiments reported here demonstrate that the effects of a nutritional shift-up on yeast RNA production do differ from those on bacterial RNA production: in yeast the increase in the rate of stable RNA synthesis does not follow immediately upon enrichment of the culture medium. The effects of shift-up on the levels of rRNA and tRNA in yeast are also described.

\section{METHODS}

Organism and growth conditions. All experiments used Saccharomyces cerevisiae strain FL52I (ura-2;a). This strain carries a deletion in the structural gene for aspartate transcarbamylase (M. L. Bach, personal communication) and therefore cannot synthesize any pyrimidine endogenously but will grow when provided with uracil or cytosine. Growth of liquid cultures at $30^{\circ} \mathrm{C}$ was measured turbidimetrically in a Klett-Summerson colorimeter using a blue filter (about $430 \mathrm{~nm}$ ).

The basal medium contained $\left(1^{-1}\right): 5 \mathrm{~g}$ yeast nitrogen base without amino acids or ammonium sulphate (Difco); $20 \mathrm{~g}$ glucose; $2 \mathrm{~g}$ L-proline; and $10 \mathrm{mg}$ uracil. Cells grew in this medium with a steady-state generation time of about $4 \mathrm{~h}$. The basal medium was enriched by the addition of 0.01 volumes of an amino acid mixture containing $\left(\mathrm{g}^{-1}\right)$ : L-alanine, 2.76; L-arginine, 2.5 I L-aspartic acid, 5.48; L-cysteine, 0.97; L-glutamic acid, 6.35; glycine, I·79; L-histidine, I-IO; L-isoleucine, 2.95; L-leucine, 4.68; L-lysine, $4 \cdot 12$; L-methionine, I.06; L-phenylalanine, 4.90; L-serine, 2.26; L-threonine, 2.28; L-tryptophan, I.02; L-tyrosine, 2.27; and L-valine, 3.32. These are the proportions (by weight) of amino acids in total yeast protein (Y. Boulanger, personal communication). During steady-state growth in this enriched medium the doubling time was about $2 \mathrm{~h}$.

Measurement of RNA accumulation. The incorporation of radioactive uracil into acidinsoluble material was used to estimate the accumulation of RNA. The radioactive precursors were added to cultures as indicated in the text and samples were removed at intervals into ice-cold $5 \%(\mathrm{w} / \mathrm{v})$ trichloroacetic acid (TCA) for $\mathrm{I} h$. Precipitates were collected on membrane filters, washed three times with Io $\mathrm{ml}$ cold. TCA and once with $5 \mathrm{ml}$ cold water. The filters were dried and then mixed with ro $\mathrm{ml}$ toluene containing $0.5 \%$ (w/v) 2,5-diphenyloxazole and counted in an Intertechnique SL30 spectrometer.

Extraction and electrophoretic analysis of RNA. The isolation of total RNA from yeast and its separation into rRNA and tRNA species by polyacrylamide gel electrophoresis were done as described previously (Waldron \& Lacroute, 1975). To achieve separation of all these species in one gel slab, instead of the previous two, the system was modified in that the lower half of the slab consisted of $7.5 \%$ polyacrylamide and the upper half was a composite gel of $2.5 \%$ polyacrylamide strengthened with $0.5 \%$ agarose.

\section{RESULTS}

\section{Accumulation of RNA during shift-up}

Cells were incubated overnight in basal medium to obtain a slow-growing culture in a balanced state of growth. RNA accumulation was measured by adding $\left[{ }^{14} \mathrm{C}\right]$ uracil $(0.05 \mu \mathrm{Ci}$ $\mathrm{ml}^{-1}$; $10 \mu \mathrm{g} \mathrm{ml}^{-1}$ ) to the medium throughout the incubation. When the turbidity reached about 20 Klett units the medium was supplemented with an amino acid mixture (Fig. I). Culture turbidity, which was proportional to the total dry weight (Waldron \& Lacroute, 1975), did not change during the early part of the shift-up. This initial arrest was not due to 


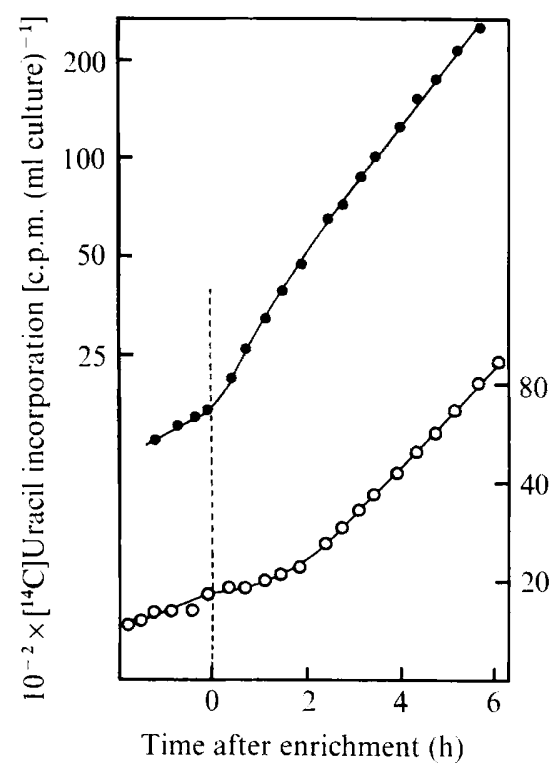

Fig. 1

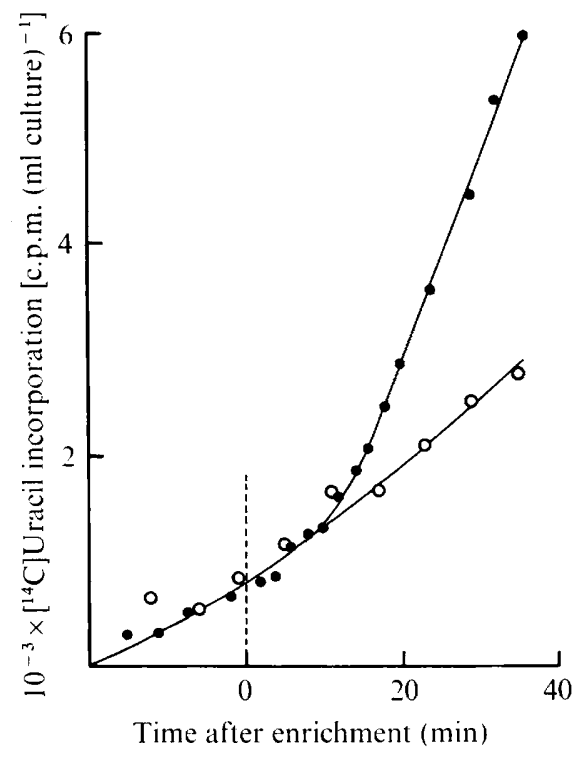

Fig. 2

Fig. I. Effects of shift-up on RNA content and culture turbidity. Cells were grown overnight in the presence of $\left[{ }^{14} \mathrm{C}\right]$ uracil. At time zero (- - ) the medium was enriched by addition of an amino acid mixture. Samples were withdrawn at intervals to determine RNA content by the amount of $\left[{ }^{14} \mathrm{C}\right]$ uracil incorporated into acid-insoluble material (O). Culture turbidity was measured in a Klett-Summerson colorimeter throughout the experiment $(O)$.

Fig. 2. Effect of shift-up on RNA accumulation. Cells were grown overnight in basal medium. Twenty min before enrichment, $\left[{ }^{14} \mathrm{C}\right]$ uracil was added and the culture immediately divided into two parts. At time zero (-- ) one culture was enriched by addition of an amino acid mixture. Samples were withdrawn at intervals to determine RNA content by the amount of $\left[{ }^{14} \mathrm{C}\right]$ uracil incorporated into acid-insoluble material in the enriched $(\odot)$ and control $(O)$ cultures.

inhibition of metabolism because RNA began to accumulate soon after the enrichment (see below). The initial increases in these macromolecules must therefore have been offset by the disappearance of others. In the experiment illustrated in Fig. I, the rate of RNA accumulation increased shortly after enrichment to a rate even faster than that characteristic of the enriched medium, and then gradually declined. After about $2.5 \mathrm{~h}$ a new state of balanced growth was established when both RNA and turbidity were increasing at a constant exponential rate (indicated by straight lines on the semi-logarithmic plot of Fig. I). The occurrence of a rapid rate of RNA accumulation soon after enrichment seems to depend on the magnitude of the shift-up; when the difference between pre- and post-shift growth rates was less marked than in the experiment of Fig. I the increased rate of RNA accumulation often did not exceed that which was characteristic of the enriched medium (unpublished observations).

In experiments such as that illustrated in Fig. I, the curve of post-shift RNA accumulation did not extrapolate back to the pre-shift line exactly at the time at which the amino acids were added. This suggested there may have been a short lag before the rate of stable RNA production increased. To demonstrate this lag it was necessary to label the cells with $\left.{ }^{[14} \mathrm{C}\right]$ uracil $\left(0.5 \mu \mathrm{Ci} \mathrm{ml}^{-1}\right.$; Io $\left.\mu \mathrm{g} \mathrm{ml}^{-1}\right)$ for only a short period before the amino acids were added. This procedure emphasized the differences between samples taken at short intervals but the precision of the early time points was reduced due to low incorporation. 


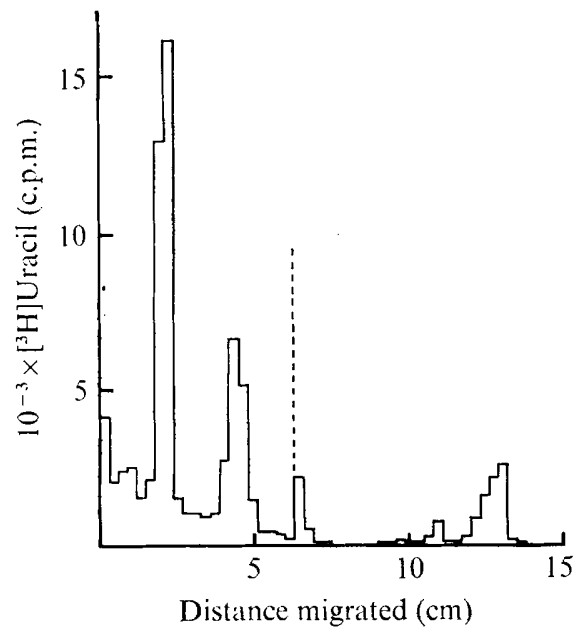

Fig. 3

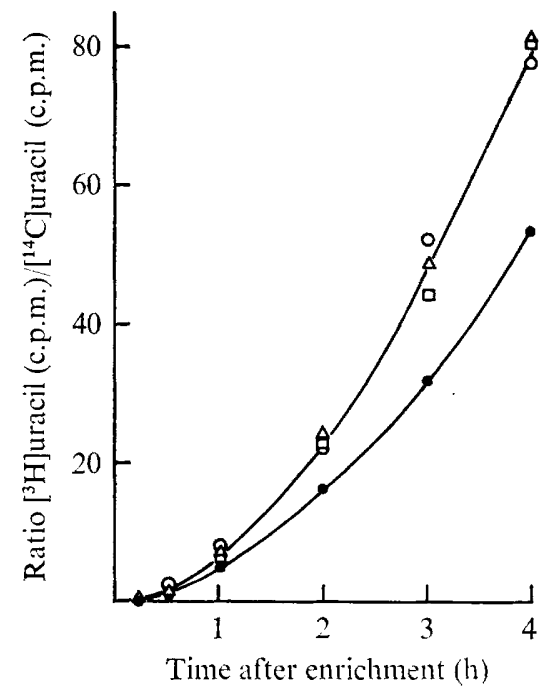

Fig. 4

Fig. 3. Electrophoretic separation of total yeast RNA. Cells were grown overnight in basal medium which was then enriched by addition of an amino acid mixture. At the time of enrichment $\left[{ }^{3} \mathrm{H}\right]$ uracil was added to the culture and $4 \mathrm{~h}$ later the cells were harvested. The RNA was extracted and then subjected to electrophoresis through a slab consisting of a layer of $2.5 \%$ polyacrylamide with $0.5 \%$ agarose, to the left of the interface (-- ), above a layer of $7.5 \%$ polyacrylamide, to the right of the interface.

Fig. 4. Effect of shift-up on rRNA and tRNA production. Cells were grown overnight in basal medium in the presence of $\left.{ }^{14} \mathrm{C}\right]$ uracil. The cells were collected on membrane filters and resuspended in basal medium containing non-radioactive uracil. After $2.5 \mathrm{~h}$ further incubation, the medium was enriched by addition of an amino acid mixture. $\left[{ }^{3} \mathrm{H}\right]$ uracil was also added. The RNA was extracted from samples withdrawn at intervals after the enrichment and was separated into its component species by polyacrylamide gel electrophoresis. The amounts of $\left[{ }^{3} \mathrm{H}\right]$ uracil (normalized to $\left[{ }^{14} \mathrm{C}\right]$ uracil) in each band of the gels were determined for $25 \mathrm{~S}$ and $5.8 \mathrm{~S}$ rRNA $(\triangle), 18 \mathrm{~S}$ rRNA $(\square), 5 \mathrm{~S}$ rRNA $(O)$ and ${ }_{4} \mathrm{~S}$ tRNA (O).

Consequently, a linear plot of incorporation versus time was used for these data so the curves could be extrapolated back to the origin. This experiment revealed that the rate of RNA accumulation did not differ from that of the non-supplemented control until about io min after the amino acids had been added (Fig. 2).

\section{Production of $r R N A$ and $t R N A$ during shift-up}

The production of these RNA species was followed during a shift-up to determine at what stage of the transition a new balance was established. Total yeast RNA was separated using a two-phase gel system (Fig. 3). The slowest moving band consisted of $25 \mathrm{~S}$ rRNA and $5.8 \mathrm{~S}$ rRNA which were only separated under strongly dissociating conditions (Udem, Kaufman \& Warner, 197I). The I8 S rRNA migrated about $4 \mathrm{~cm}$ in the gel (Fig. 3) and the 5S rRNA about II $\mathrm{cm}$. The fastest moving band was $4 \mathrm{~S}$ tRNA. The material at the interface was probably heterogeneous RNA which was too small to be retarded by the $2.5 \%$ gel, yet too large to migrate far into the $7.5 \%$ gel.

When measuring the rate of appearance of radioactivity in bands of a gel it is important to correct for any variations due to extraction efficiency or size of the applied sample. I therefore adopted a double-labelling protocol so that radioactivity in stable RNA made 
before the shift-up could be assayed as a measure of the amount of RNA present in each band. Cells were labelled by incubation overnight in basal medium containing $\left[{ }^{14} \mathrm{C}\right]$ uracil ( $2 \mu \mathrm{Ci} \mathrm{ml}{ }^{-1}$; Io $\mu \mathrm{g} \mathrm{ml}^{-1}$ ), collected on sterile membrane filters, washed with prewarmed, non-radioactive medium and resuspended in basal medium containing only unlabelled uracil. The incubation was continued for another $2.5 \mathrm{~h}$ before shift-up so that the $\left[{ }^{14} \mathrm{C}\right]$ uracil was chased into stable RNA species only. That such stable RNA contained rRNA and tRNA species in the same proportions as was present in cells at steady-state was demonstrated by the following experiment. Cells were labelled as described above but, in addition, $\left[{ }^{3} \mathrm{H}\right]$ uracil $\left(2 \mu \mathrm{Ci} \mathrm{m}{ }^{-1}\right)$ was present in the medium, both before and after removal of the $\left[{ }^{14} \mathrm{C}\right]$ uracil, to label RNA in its steady-state distribution. Following extraction and electrophoresis, the ${ }^{3} \mathrm{H} /{ }^{14} \mathrm{C}$ ratio was found to be essentially the same in all major bands $(2 \cdot 7 \mathrm{I}$ for the $25 \mathrm{~S}-5 \cdot 8 \mathrm{~S}$ band, $2 \cdot 74$ for the $18 \mathrm{~S}$ band, $2 \cdot 30$ for the $5 \mathrm{~S}$ band, and $2 \cdot 4 \mathrm{I}$ for the $4 \mathrm{~S}$ band). Thus, the radioactivity chased into stable RNA was used to correct for variations in the yield of any rRNA or tRNA species.

To determine the effects of shift-up on rRNA and tRNA, stable RNA was first labelled with $\left[{ }^{14} \mathrm{C}\right]$ uracil as described above, then $\left[{ }^{3} \mathrm{H}\right]$ uracil $\left(40 \mu \mathrm{Ci} \mathrm{ml}^{-1}\right)$ was added with the amino acid mixture to label RNA synthesized exclusively after the enrichment. The RNA was then extracted from samples withdrawn at intervals after shift-up and subjected to electrophoresis. The amount of each RNA produced at different times after the shift was determined from the amount of ${ }^{3} \mathrm{H}$ radioactivity in the bands, corrected for variations in yield by normalizing ${ }^{3} \mathrm{H}$ to ${ }^{14} \mathrm{C}$ counts (Fig. 4). Following shift-up all the rRNA species increased continuously and at the same rate; the tRNA also increased continuously, but at a slower rate than the rRNA. Throughout the transition the ${ }^{3} \mathrm{H} /{ }^{14} \mathrm{C}$ ratio for tRNA was only $70 \%$ of the ratio for rRNA species.

\section{DISCUSSION}

There are a number of mechanisms by which the production of stable RNA (mainly rRNA) may be controlled in yeast. These mechanisms can be broadly classified into two categories, depending on whether rRNA production is limited by the activity of a component of the synthesizing system, or by the number of molecules of a component. If synthesis is controlled by a component's activity, then shift-up may be expected to generate an immediate response, as seen in bacteria. My observation that enrichment does not produce an immediate increase in the rate of RNA accumulation seems to argue against these models. Further evidence against one such model, in which polymerase activity could be controlled by the rate of transcription, is provided by measurements showing that the chain completion times of rRNA precursors do not vary greatly with growth rate (C. Waldron, F. Lacroute \& R. Jund, unpublished results). Another model, in which there is activation of pre-existing, non-functional polymerase molecules, is not applicable because there is a lag following shift-up before the specific activity of RNA polymerase I increases (Carter \& Dawes, 1975). It therefore seems that stable RNA production is regulated by the availability of RNA polymerase I molecules or its substrates (nucleotide triphosphates and the cistrons coding for rRNA). Transient reduction in the supply of either of these substrates cannot be excluded as the cause of the lag before stable RNA production increases. However, the levels of nucleotide triphosphates are not affected by shift-down (Kudrna \& Edlin, 1975) and the number of rRNA cistrons does not change with different steady-state growth rates (Schweizer \& Halvorson, 1969) so their supply does not normally limit rRNA synthesis. Thus, the data can be most readily explained by the model of Sebastian, Mian \& Halvorson (1973) in which the major factor controlling rRNA production in yeast is the number of RNA 
polymerase I molecules per cell, with all these molecules operating at near maximum efficiency.

The effects of nutritional shift-up on rRNA and tRNA production confirm our previous suggestion that the levels of these RNA species in yeast are controlled to similar yet different extents (Waldron \& Lacroute, 1975). There is not a burst of synthesis on one type of RNA followed by a burst of synthesis of the other, but all types accumulate continuously throughout the transition. Furthermore, all the rRNA species (including the ${ }_{5} \mathrm{~S}$ rRNA) are synthesized in equimolar amounts at a rate which is always $30 \%$ faster than the rate of tRNA synthesis. These constant relationships are not achieved by one polymerase synthesizing all stable RNA species since in yeast cells treated with lomofungin the production of high molecular weight rRNA is blocked while $5 \mathrm{~S}$ rRNA and ${ }_{4} \mathrm{~S}$ tRNA continue to accumulate (Fraser, Creanor \& Mitchison, 1973). It is probable that in yeast, by analogy with higher eukaryotes (Weinmann \& Roeder, 1974), the $25 \mathrm{~S}$, I8S and $5.8 \mathrm{~S}$ rRNA species are synthesized by RNA polymerase I and the $5 \mathrm{~S}$ rRNA and $4 \mathrm{~S}$ tRNA are synthesized by different forms of RNA polymerase III. The activities of these polymerases could be co-ordinated by them all requiring a common sub-unit (Valenzuela et al., 1976). The difference in accumulation rate may be due to the component having a lower affinity for the form of RNA polymerase III synthesizing tRNA. Such a regulatory component would not be affected by lomofungin; it may be the product of one of the genes in which mutation affects production of all RNA species (Lacroute, Huet \& Exinger, 1975; Thonart et al., 1976).

During the course of this work I was a Postdoctoral Research Fellow of the Royal Society European Exchange Programme.

\section{REFERENCES}

Adman, R., Schultz, L. D. \& Hall, B. D. (1972). Transcription in yeast: separation and properties of multiple RNA polymerases. Proceedings of the National Academy of Sciences of the United States of America 69, I 702-1706.

Boehlke, K. W. \& Friesen, J. D. (1975). Cellular content of ribonucleic acid and protein in Saccharomyces cerevisiae as a function of exponential growth rate: calculation of the apparent peptide chain elongation rate. Journal of Bacteriology 121, 429-433.

Bremer, H., BerRy, L. \& DeNNIS, P. P. (I973). Regulation of ribonucleic acid synthesis in Escherichia coli $\mathrm{B} / \mathrm{r}$ : an analysis of shift-up. II. Fraction of RNA polymerase engaged in the synthesis of stable RNA at different steady-state growth rates. Journal of Molecular Biology 75, I6I-1 79.

Burgess, R. R., Travers, A. A., DunN, J. J. \& Bautz, E. K. F. (1969). Factor stimulating transcription by RNA polymerase. Nature, London 221, 43-46.

Carter, B. L. A. \& Dawes, I. W. (I975). Synthesis of two DNA-dependent RNA polymerases in yeast. Experimental Cell Research 92, 253-258.

Fraser, R. S. S., CREANOR, J. \& Mitchison, J. M. (1973). Rapid and selective inhibition of high molecular weight RNA in yeast by lomofungin. Nature, London 244, 222-224.

KudRna, R. \& Edin, G. (I975). Nucleotide pools and regulation of ribonucleic acid synthesis in yeast. Journal of Bacteriology I2I, 740-742.

Lacroute, F., Huet, J. \& Exinger, F. (1975). Dominant and semidominant mutations leading to thermosensitivity of ribonucleic acid biosynthesis in Saccharomyces cerevisiae. Journal of Bacteriology 122, 847854.

NIERLICH, D. P. (I972). Regulation of ribonucleic acid synthesis in growing bacterial cells. II. Control over the composition of the newly made RNA. Journal of Molecular Biology 72, 765-777.

Ponta, H., Ponta, U. \& Wintersberger, E. (1972). Purification and properties of DNA-dependent RNA polymerase from yeast. European Journal of Biochemistry 29, I I0-1 18.

Rosset, R., Julien, J. \& MoniER, R. (I966). Ribonucleic acid composition of bacteria as a function of growth rate. Journal of Molecular Biology 18, 308-320.

SchweIzer, E. \& Halvorson, H. O. (1969). On the regulation of ribosomal RNA synthesis in yeast. Experimental Cell Research 56, 239-244.

Sebastian, J., Mian, F. \& Halvorson, H. O. (1973). Effect of the growth rate on the level of DNA-dependent RNA polymerases in Saccharomyces cerevisiae. FEBS Letters 34, 159-162. 
Skjold, A. C., JuARez, H. \& HedgCoth, C. (1973). Relationships among deoxyribonucleic acid, ribonucleic acid and specific transfer ribonucleic acids in Escherichia coli $15 \mathrm{~T}^{-}$at various growth rates. Journal of Bacteriology I15, $177-187$.

Thonart, P., Bechet, J., Hilger, F. \& Burny, A. (I976). Thermosensitive mutations affecting ribonucleic acid polymerases in Saccharomyces cerevisiae. Journal of Bacteriology 125, 25-32.

Udem, S. A., Kaufman, K. \& Warner, J. R. (197I). Small ribosomal ribonucleic acid species of Saccharomyces cerevisiae. Journal of Bacteriology 105, 10 I-106.

Valenzuela, P., Hager, G. L., Weinberg, F. \& RutTer, W. J. (I976). Molecular structure of yeast RNA polymerase III. Demonstration of the tripartite transcriptive system in lower eukaryotes. Proceedings of the National Academy of Sciences of the United States of America 73, 1024-1028.

WALdRon, C. \& LACroute, F. (1975). Effect of growth rate on the amounts of ribosomal and transfer ribonucleic acids in yeast. Journal of Bacteriology 122, 855-865.

Wehr, C. T. \& Parks, L. W. (I969). Macromolecular synthesis in Saccharomyces cerevisiae in different growth media. Journal of Bacteriology 98, 458-466.

WEINMANN, R. \& ROEDER, R. G. (I974). Role of DNA-dependent RNA polymerase III in the transcription of the tRNA and 5 S RNA genes. Proceedings of the National Academy of Sciences of the United States of America 71, I790-1794. 